\title{
PENGEMBANGAN USAHA TERPADU PADI SAWAH DAN TERNAK UNGGAS ALTERNATIF KECUKUPAN PANGAN DAN PENDAPATAN BAGI MASYARAKAT DI WILAYAH PERI URBAN
}

\author{
Mukhtar Abu', Achmad Selamet Aku², Deki Zulkarnain², La Ode Jabuddin \\ ${ }^{1)}$ Staf Pengajar Pada Jurusan Agribisnis Fakultas Pertanian Universitas Halu Oleo, Kendari \\ ${ }^{2)}$ Staf Pengajar Pada Jurusan Peternakan Fakultas Peternakan Universitas Halu Oleo, Kendari \\ email: achmad.s.aku@gmail.com
}

\begin{abstract}
ABSTRAK
Integrasi usahatani ternak merupakan pilihan untuk menunjang peningkatan pendapatan petani baik yang ada di pedesaan maupun di daerah pingiran kota yang masih memiliki lahan pertanian khususnya persawahan. Penelitian ini bertujuan (1) mengetahui tingkat pendapatan petani padi sawah dengan usaha tunggal di Kawasan Persawahan Amohalo (2) menganalisis potensi peningkatan pendapatan petani dengan mengintegrasikan usaha tani padi sawah dengan usaha ternak itik, (3) menganalisis keberhasilan dan kemanfaatan secara ekonomi pada usaha tunggal dan usaha integrasi padi sawah dengan usaha ternak itik. Responden dalam penelitian ini adalah petani padi sawah yang memiliki ternak dengan jumlah 33 petani. Penentuan responden dilakukan secara acak sederhana yang selanjutnya dilakukan analisis pendapatan. Hasil penelitian menunjukkan bahwa(1) pada usahatani tunggal, jumlah pendapatan bersih yang diperoleh petani padi sawah di Kawasan Persawahan Amohalo adalah sebesar Rp7.716.295,58,- per tahunnya,- atau hanya sebesar Rp643.024.63,- per bulanya, (2) Pada usahatani integrasi, jumlah pendapatan bersih yang diperoleh petani di Kawasan Persawahan Amohalo adalah sebesar Rp14.464.495,58,- per tahunnya,- atau sebesar Rp1.205.374,63,-,dan (3) pola usahatani padi sawah yang terintegrasi dengan ternak itik, lebih efisien dan menguntungkan dari pada usahatani tunggal. Pada usahatani tunggal diperoleh nilai $\mathrm{R} / \mathrm{C}$ ratio sebesar 1,69 sedangkan usahatani yang terintegrasi diperoleh nilai $\mathrm{R} / \mathrm{C}$ ratio sebesar 2,05.
\end{abstract}

Kata kunci: Pengembangan, Integrasi usahatani ternak, pendapatan

\begin{abstract}
Integrated farming System has become an option the support of increase income of farmers both in rural and in suburbs that still have agricultural land, especially rice fields..The study aimed to know the income level of rice farmers with single effort in Rice Field, it was analyze farmer income potency by integrating rice farming business with duck livestock, and the economic benefit in single business and integration farming system of field rice and with duck business. Respondents in this study are rice farmers who have livestock with 33 farmers. The determination of the respondents was done by simple random sampling which then conducted the income analysis.) The results showed that (1) on a single farm, the net income earned by paddy farmers in Amawalo Peatland Area was Rp7,716,295.58 per year, or only Rp643.024.63 per month, (2) In the integration farm, the net income earned by farmers in Amohalo Rice Farming Area is Rp14.464.495.58, - per year, - or Rp.1,205,374.63, -, and (3) rice farming pattern integrated with ducks, more efficient and profitable than a single farm. The results showed that a single farming value obtained $\mathrm{R} / \mathrm{C}$ ratio of 1.69 while the integrated farming system value obtained $\mathrm{R} / \mathrm{C}$ ratio of 2.05.)
\end{abstract}

Key word : Development, Integrated farming system, income 


\section{PENDAHULUAN}

Program peningkatan ketahanan pangan diarahkan untuk dapat memenuhi kebutuhan pangan masyarakat di dalam negeri dari produksi pangan nasional. Berbagai upaya telah ditempuh pemerintah melalui kegiatan pengamanan lahan sawah di daerah irigasi, peningkatan mutu intensifikasi serta optimalisasi dan perluasan areal pertanian. Salah satu bahan pangan nasional yang diupayakan ketersediaannya tercukupi sepanjang tahun adalah beras yang menjadi makanan pokok bagi sebagian besar penduduk Indonesia (Sahara dan Idris, 2006).

Selain itu upaya pengembangan usaha tani-ternak dalam waktu yang bersamaan merupakan suatu bentuk usaha yang umumnya dilaksanakan dipedesaan, sekalipun dengan skala prioritas hanya pada usaha tani sebagai usaha utama sedangkan usaha ternaknya sebagai kegiatan sambilan dan bukan menjadi prioritas usaha yang menopang ekonomi keluarga, sehingga perhatian utama petani lebih banyak pada usaha taninya. Kondisi seperti ini telah menjadi fenomena sistem pertanian di Sulawesi Tenggara termasuk sistem usahatani-ternak pada masyarakat di Kota Kendari khususnya pada daerah pingggiran sebagai penyanggah pangan masyarakat Kota Kendari.

Integrasi usahatani ternak dewasa ini telah menjadi pilihan untuk menunjang peningkatan petani baik yang ada di pedesaan maupun di daerah pingiran kota yang masih memiliki lahan pertanian khususnya persawahan. Studi-studi tentang manfaat melakukan integrasi usahatani padi sawah dengan peternakan telah banyak dilakukan, Atmojo (2007); Karda dan Spudiati, (2012) tentang integrasi tanaman pertanian dengan ternak sapi; Pujiatmoko (2009); Setioko, dkk (2010); tentang Integrasi itik dengan pertanian padi sawah.

Untuk menyanggah sebagian dari kebutuhan pangan masyarakat kota kendari khususnya beras, pemerintah Kota Kendari mengembangkan dua lokasi persawahan yaitu persawahan Amohalo seluas $700 \mathrm{Ha}$ dan persawahan Labibia seluas $100 \mathrm{Ha}$.
Asrun (2014) menyatakan bahwa produksi padi dari dua titik persawahan itu terus mengalami peningkatan di atas lima persen per tahun sehingga kota Kendari pernah mendapatkan penghargaan bidang ketahanan pangan. BPS Kota Kendari (2013) melaporkan bahwa luas panen padi sawah pada tahun 2012 adalah $780 \mathrm{Ha}$ yang merupakan salah satu potensi yang bisa dikembangkan dengan usaha lainnya secara terintegrasi khususnya integrasi sawah dengan ternak.

Sekalipun demikian upaya mengintegrasikan tanaman pangan khususnya sawah dan ternak di Kota Kendari belum dilakukan secara optimal. Sistem pemeliharaan sapi disekitar persawahan yang ada di Kota Kendari umumnya hanya dilakukan sekedarnya atau dengan kata lain ternak sapi yang dilepaskan di seitar areal persawahan hanya sekedar untuk memberikan ruangan kepada ternak sapi dalam mencari makan, tanpa perencanaan yang bermakna seperti yang diharapkan dari konsep integrasi ternak dan pertanian khususnya pertanian tanaman pangan. Berdasarkan pemikiran tersebut, maka permasalahan dalam kajian ini meliputi; (a) bagaimana tingkat pendapatan petani padi sawah dengan usaha tunggal pada petani di Kawasan Persawahan Amohalo Kecamatan Baruga Kota Kendari, (b) bagaimana potensi peningkatan pendapatan petani di Kawasan Persawahan Amohalo Kecamatan Baruga Kota Kendari yang mengintegrasikan usaha tani padi sawah dengan usaha ternak itik, dan (c) sejauhmana keberhasilan dan kemanfaatan secara ekonomi pada usaha tunggal dan usaha integrasi padi sawah dengan usaha ternak itik.

\section{METODE PENELITIAN}

\section{Lokasi dan Waktu Penelitian}

Penelitian ini dilaksanakan di Kecamatan Baruga Kota Kendari pada tahun 2014, selama 3 bulan. Objek yang dijadikan sasaran dalam penelitian ini adalah Keluarga petani peternak yang memiliki usahatani padi sawah. 


\section{Populasi dan Teknik Pengumpulan Data}

Populasi dalam peneltian ini adalah seluruh petani padi sawah yang berada pada Kawasan Persawahan Amohalo. Jumlah populasi yang berada pada Kawasan ini adalah kurang lebih sebanyak 130 Kepala keluarga. Pengambilan petani sampel dilakukan secara acak sederhana atau simple random sampling, yang berarti bahwa dari tiap-tiap petani yang memenuhi persyaratan sebagai petani sampel dipilih secara acak. Menurut Guilford (1987) dalam Supranto (1997), jika jumlah populasi relatif besar dan relatif homogen, maka sampel penelitian meliputi sejumlah elemen (responden) yang lebih besar dari persyaratan minimal sebanyak 30 elemen (responden). Berdasarkan pernyataan tersebut, maka sampel dalam penelitian ini berjumlah 33 responden (kepala keluarga).

\section{Variabel Penelitian}

Variabel yang diteliti dalam penelitian ini adalah sebagai berikut:

- Ketersediaan sarana penunjang dalam kegiatan usahatani

- Karakteristik responden, meliputi: umur, jumlah tanggungan keluarga, tingkat pendidikan dan pengalaman berusahatan.

- Karakteristik usahatani, yang terdiri dari luas lahan garapan, penggunaan benih, pupuk, pestisida, tenaga kerja dan produksi.

- Biaya produksi, meliputi nilai penyusutan peralatan, nilai benih, pupuk, pestisida dan biaya tenaga.

- Penerimaan dan pendapatan

\section{Analisis Data}

- Untuk mengetahui data dan informasi mengenai tingkat pendapatan responden, digunakan analisis deskriptif kualitatif. (Sugiyono, 2012).

- Untuk mengetahui peningkatan pendapatan petani padi sawah dengan usaha tunggal dan integrasi pada petani di Kawasan Persawahan Amohalo Kecamatan Baruga Kota Kendari, digunakan analisis fungsi keuntungan menurut Diwyanto et al. (2002) dengan persamaan sebagai berikut:

$$
\begin{aligned}
\mathrm{TT} & =\mathrm{TR}-\mathrm{TC} \\
& =\mathrm{TR}-(\mathrm{VC}+\mathrm{F}) \\
& =\text { Py. } \mathrm{Y}-\mathrm{Px} \cdot \mathrm{X}-\mathrm{F}
\end{aligned}
$$

Dimana;

$$
\begin{array}{ll}
\mathrm{TT} & =\text { fungsi keuntungan } \\
\mathrm{Py} & =\text { harga produk yang } \\
\text { diproduksi } & \\
\mathrm{Y} & =\text { fungsi produksi, } \mathrm{f}(\mathrm{Y}) \\
\mathrm{P} & =\text { harga masing-masing input } \\
(\mathrm{Xi}) & \\
\mathrm{X} & =\text { input yang digunakan } \\
\mathrm{F} & =\text { biaya tetap } \\
\mathrm{Py} . \mathrm{Y} & =\text { total penerimaan }(\mathrm{TR}) \\
\mathrm{Px} . \mathrm{X}+\mathrm{F} & =\text { total biaya }(\mathrm{TC})
\end{array}
$$$$
\text { (Xi) }
$$

- Untuk mengetahui keberhasilan dan kemamfaatan secara ekonomi mengenai penggunaan biaya pada usaha tunggal dan integrasi, diukur dengan menggunakan analisis R/C-Ratio menurut Soeharjo dan Patong (1984) sebagai berikut :

$$
\mathrm{R} / \mathrm{C}=\frac{\mathrm{TR}}{\mathrm{TC}}
$$

dengan kriteria ;

- Jika R/C > 1, maka usaha layak secara ekonomis (untung)

- Jika R/C = 1, maka usaha impas (tidak untung dan tidak rugi)

- Jika R/C < 1, maka usaha tidak layak secara ekonomis (rugi).

\section{HASIL DAN PEMBAHASAN}

\section{Ketersediaan Sarana Penunjang}

Sarana dan prasarana merupakan salah satu aspek penunjang kegiatan usahatani, dimana aspek ini akan memberikan dampak terhadap keberhasilan usahatani, baik dari segi kelembagaan maupun dari segi budidaya (on farm). Berikut disajikan mengenai sarana prasarana dalam kegiatan usahatani di Kawasan Persawahan Amohalo. 
Tabel 1. Ketersediaan Sarana Prasarana Dalam Mendukung Kegiatan Usahatani Pada Kawasan Persawahan Amohalo Kecamatan Baruga Kota Kendari

\begin{tabular}{ll}
\hline Uraian & Kondisi \\
\hline a. Sarana penunjang: & \\
- Sarana jalan & Tanah \\
- Transportasi & Mobil/motor \\
- Sarana irigasi & Teknis \\
- Pasar input & Ada (tengkulak) \\
- Pasar output & Ada (pengumpul)
\end{tabular}

b. Kegiatan usahatani:

- Status lahan

- Pengolahan lahan

- Penanaman

- Panen

- Pascapanen

Milik/pinjam (bagi hasil) 1:1 dan 2:1

Traktor (milik kelompok)

Sendiri/sewa (sistem borong)

Mesin (bagi hasil) 7:1 - 9:1

Mesin (bagi Hasil 10:1)

Sumber: Data Primer Diolah

Sarana penunjang seperti jalan, trasportasi, pasar input dan pasar output merupakan salah satu syarat agar konsep agribisnis secara komperenship dapat dilaksanakan. Berdasakan data pada Tabel 1, maka hal-hal yang dapat dijelaskan adalah sebagai berikut:

\section{a. Sarana Jalan, Transportasi dan Sistem Irigasi}

Tabel 1 menunjukkan bahwa di lokasi penelitian pada Kawasan Persawahan Amohalo Kecamatan Baruga, jalan usahatani sebagai penghubung antara sektor kegiatan budidaya kondisinya masih kurang memadai. Pada musim kemarau, jalur masuk transportasi agak terhambat yang diakibatkan oleh kondisi jalan yang berdebuh dan berlubang. Begitu pula jika pada musim penghujan, jalan menjadi becek dan berlumpur terutama dari jalur Kota menuju Kawasan Persawahan Amohalo. Kondisi seperti ini akan menghambat lancarnya pengangkutan distribusi input maupun output pertanian.

Irigasi dalam persawahan merupakan usaha untuk memperoleh air yang menggunakan bangunan dan saluran buatan untuk keperluan produksi tanaman. Air merupakan faktor penting dalam bercocok tanam. Suatu sistem irigasi yang baik akan meningkatkan pertumbuhan tanaman yang optimal, antara air dan tanaman mempunyai hubungan yang erat karena pentingnya fungsi air dalam penyelenggaraan dan kelangsungan hidup tanaman. Pada Kawasan Persawahan Amohola di Kecamatan Baruga, sistem pengairan dalam pengelolaan usahatani padi sawah telah mengggunakan sistem pegairan irigasi teknis, dimana airnya bersumber dari sungai Wanggu dan Sungai Amohalo. Air irigasi diberikan dengan cara mengalirkan aliran ke permukaan tanah atau biasa disebut sistem irigasi permukaan. Cara ini merupakan cara yang paling umum digunakan dengan sistem leb dari sawah. Air dibawa lewat parit-parit secara datar dengan kecepatan rendah untuk menghindari erosi. Dengan sistem leb ini dibutuhkan waktu yang cukup untuk membiarkan air menutupi seluruh permukaan tanah agar dapat diserap oleh akar tanaman. Hal ini dilakukan agar kelembapan tanah tetap terjaga, membantu menyuburkan tanah melalui bahan-bahan kandungan yang dibawa oleh air, meningkatkan penggunaan pupuk dan obatobatan dalam hal penghematan penggunaanya, dapat menekan pertumbuhan gulma dan pertumbuhan hama penyakit tertentu serta dapat memudahkan pengelolaan tanah.

Berdasarkan hasil survei dan wawancara dengan petani responden, diperoleh informasi bahwa penggunaan air irigasi dalam memanfaakan siklus produksi pada usahatani padi sawah belum efektif. Hal ini dapat diketahui dengan masih kurang 
intensifnya penggunaan lahan pada usahatani, dimana dalam sata tahun hanya melakukan penanaman sebanyak 2 (dua) kali. Padahal sesungguhnya dengan adanya ketersediaan sumber air irigasi, intensitas kegiatan produksi dapat dilakukan sepanjang tahun, agar produksi dan pendapatan petani dapat menjadi lebih meningkat. Kondisi seperti ini dapat disebabkan karena debet air sungai Wanggu dan Amohalo sudah berkurang akibat perambahan dan pengrusakan vegetasi di sekitar hulu sungai. Selain itu, juga dapat disebabkan karena kondisi kontruksi sarana irigasi sudah mulai rusak, sehingga berpengaruh pada proses distribusi air dalam pematang-pematang sawah.

\section{b. Pasar Input dan Pasar Output}

Pada Kawasan Persawahan Amohalo terdapat pasar input dan pasar output. Pasar input yang dimaksud adalah tersedianya saran produksi seperti pupuk dan obatobatan di lokasi usahatani. Namun faktanya bahwa para penyedia input tersebut berperan sebagai tengkulak. Artinya bahwa pada saat petani membutuhkan input tersebut dalam kegiatan produksi walaupun tidak mempunyai uang tunai, petani dapat memperolehnya secara mudah dengan catatan akan dibayarkan setelah panen dan harga yang relatif lebih mahal jika dibandingkan dengan pembayaran tunai. Kondisi tersebut tentunya akan beresiko bagi petani, karena jika terjadi kegagalan panen (paceklik) maka beban tersebut akan menjadi utang petani. Sedangkan pasar output yang dimaksud adalah tersedianya pedagang dilokasi usahatani, dimana mereka bertindak sebagai pedagang pengumpul yang membeli langsung hasil panen para petani. Kondisi ini tentunya akan menguntungkan petani, karena petani tidak lagi mengeluarkan biaya pemasaran (biaya transportasi) yang akan mempengaruhi total pendapatan petani.

\section{c. Status Kepemilikan Lahan}

Tabel 2 diperoleh informasi bahwa kepemilikan lahan yang digunakan petani dalam melakukan kegiatan produksi, yaitu ada yang berstatus milik dan ada yang berstatus pinjam. Status kepemilikan lahan dengan meminjam merupakan salah satu implementasi kelembagaan antara individuindividu petani. Dalam proses ini terjadi kesepekatan bersama antara pihak pemilik dan peminjam. Pada Kawasan Persawahan Amohalo yang terjadi adalah adanya kesepakatan para pihak dalam hal bagi hasil panen. Jika pemilik lahan menanggung semua input dalam proses produksi, maka perbandingan sistem bagi hasil panen adalah $1: 1$, artinya, bila hasil panen sebanyak 30 karung, maka pemilik dan peminjam lahan masing-masing memperoleh 25 karung. Namun jika pemilik lahan tidak menanggung semua input (petani peminjam yang menanggung biaya dalam proses produksi), maka perbandingan sistem bagi hasil panennya adalah $2: 1$, artinya, bila hasil panen sebanyak 30 karung, maka pemilik lahan memperoleh 10 karung dan peminjam lahan memperoleh 20 karung.

\section{d. Pengolahan Tanah dan Penanaman}

Untuk kegiatan pengolahan lahan sawah di Kawasan Persawahan Amohalo, mereka menggunakan fasilitas input milik kelompok. Fasilitas input yang dimaksud adalah handtractor, dimana alat ini merupakan milik bersama yang tergabung dalam kelompok tani atau gapoktan. Jadi telah terjadi perubahan atau transformasi teknologi dari membajak manual (luku) menjadi membajak modern (teknologi). Dalam pengoperasian handtractor ini, juga telah diatur dan disepakati bersama mengenai tata cara pemakaian dan pemeliharaannya. Jika petani yang menggunakannya adalah anggota kelompok tani dan mampu untuk mengoperasikannya sendiri, maka biaya yang dikeluarkan adalah hanya biaya bahan bakar dan pemeliharaan. Sedangkan jika petani yang menggunakannya adalah anggota kelompok tani dan tidak mampu untuk mengoperasikannya sendiri, maka biaya yang dikeluarkan adalah biaya bahan bakar, pemeliharaan dan biaya operator. Tetapi jika yang menggunakannya adalah petani yang bukan anggota kelompok tani, maka petani 
tersebut akan menyewa handtractor ini secara keseluruhan, dengan biaya yang telah disepakati (biasanya $\mathrm{Rp} 1.200 .000$ per hektar). Biaya sewa ini akan menjadi simpanan bersama yang digunakan untuk keperluan pemeliharaan alat dan kebutuhankebutuhan lainnya dalam kelompok tani. Sedangkan untuk kegiatan penanaman, petani padi sawah di Kawasan Persawahan Amohalo memanfaatkan tenaga sewa dengan sistem borong atau menggunakan tenaga kerja dalam keluarga. Penerapan sistem kerja pada kedua kegiatan usahatani tersebut, merupakan bagian dari sistem mitra dan kerjasama yang terbentuk di tingkat petani.

\section{e. Panen dan Pascapanen}

Dari Tabel 2 diperoleh informasi bahwa petani padi sawah di Kawasan Persawahan Amohalo telah menggunakan teknologi panen yang sangat memadai, yaitu menggunakan doser pemotong padi. Prinsip kerja doser pemotong padi ini adalah otomatis, yang berarti bahwa pada saat dilakukan panen, padi dalam bentuk gabah secara otomatis akan masuk ke dalam karung, sehingga pekerja panen hanya mengorbankan tenaganya untuk memindahkan karung yang telah penuh dari doser pemotong padi ke tempat penampungan. Kondisi tersebut, juga menunjukkan telah terjadinya transformasi penggunaan teknologi dari panen tradisional ke panen modern. Hal ini tentunya sangat membantu dan menguntungkan petani terutama dalam hal waktu panen, dimana jika terjadi keterlambatan dalam memanen, maka hasil panen dapat berkurang akibat termakan hama (burung). Sedangkan pada kegiatan pascapanen, sarana mesin penggiling padi juga telah tersedia, sehingga dengan hadirnya teknologi-teknologi ini akan memacu kinerja petani dalam meningkatkan produksi dan produktivitasnya.

Dalam kegiatan panen dan pascapanen tersebut, antara petani dan pemilik teknologi telah melakukan kesepakatan bersama dalam hal biaya. Besarnya biaya yang dikeluarkan petani dalam kegiatan panen dan pascapanen dibayarkan melalui sistem bagi hasil panen, dengan menggunakan satuan karung. Jika kondisi tanaman padi dalam keadaan baik (secara kasat mata butir padinya berisi), maka perbandingan pembagiannya adalah 9 keluar 1, dan jika kondisi tanaman padi dalam keadaan kurang baik (secara kasat mata butir padinya kurang berisi), maka perbandingan pembagiannya adalah 7 keluar 1. Hal ini berarti bahwa dalam setiap 9 karung atau 7 karung hasil panen yang diperoleh, maka petani memperoleh 8 karung atau 6 karung, dan pemilik mesin memperoleh 1 karung. Sedangkan pada kegiatan pascapanen (penggilingan gabah menggunakan huller) perbandingan pembagiannya adalah 10 kelaur 1 , yang berarti bahwa dalam setiap 10 karung gabah yang digiling, maka petani memperoleh 9 karung, dan pemilik mesin memperoleh 1 karung.

\section{Produksi Padi sawah}

Produksi yang dimaksud dalam penelitian ini adalah hasil akhir dari usahatani padi sawah dalam bentuk gabah kering panen (GKP), yang dinyatakan dalam satuan $\mathrm{kg} / \mathrm{ha} / \mathrm{thn}$. Hasil besar kecilnya nya produksi padi sawah tergantung pada perann masing-masing input yang digunakan dalam kegiatan produksi. Jika input tersebut penggunaannya tepat dan efisien, maka produksi yang akan digunakan akan optimal. Hasil penelitian menunjukkan bahwa besarnya produksi yang diperoleh masingmasing responden bervariasi, berkisar antara $2100-8.800 \mathrm{~kg} / \mathrm{ha} / \mathrm{th}$, dengan produksi rata-rata sebes $5.822,22 \mathrm{~kg} / \mathrm{ha} / \mathrm{th}$. Sementara data mengenai besarnya jumlah produksi padi sawah di Kawasan Persawahan Amohalo Kecamatan Baruga disajikan pada Tabel 2. 
Tabel 2. Total Produksi Padi Sawah Di Kawasan Persawahan Amohalo Kecamatan Baruga Kota Kendari.

\begin{tabular}{cccc}
\hline No & $\begin{array}{c}\text { Jumlah Produksi } \\
(\mathrm{kg} / \mathrm{ha} / \mathrm{thn})\end{array}$ & $\begin{array}{c}\text { Jumlah } \\
\text { (jiwa) }\end{array}$ & $\begin{array}{c}\text { Persentase } \\
(\%)\end{array}$ \\
\hline 1 & $<3.000$ & 4 & 12,12 \\
2 & $3.000-6.000$ & 12 & 36,36 \\
3 & $>6.000$ & 17 & 51,52 \\
\hline
\end{tabular}

Sumber: Data Primer Diolah

Tabel 2 menunjukkan bahwa besarnya produksi dari masing-masing petani memang bervariasi. Bervariasinya jumlah produksi ini dapat disebabkan karena perbedaan rata-rata penggunaan faktorfaktor produksi seperti luas lahan garapan, penggunaan benih, pupuk, obat-obatan dan sarana produksi lainnya dari masing-masing petani responden, sehingga secara langsung akan mempengaruhi produksi yang akan dihasilkan. Sedangkan menurut Sukirno (1998) perbedaan produksi yang diperoleh petani dalam berusahatani, dapat disebabkan oleh perbedaan pengetahuan dan penguasaan penggunaan teknologi. Hal ini berkaitan erat dengan pendidikan dan pengalaman yang dimiliki oleh masingmasing petani yang pada akhirnya akan mempengaruhi tinggi rendahnya produksi yang akan dihasilkan. Namun yang perlu diketahui, bahwa penambahan satu satuan input pada lahan usahatani, mula-mula akan meningkatkan output secara cepat, kemudian penambahan satu satuan input berikutnya akan menaikkan output yang hasilnya lebih kecil dari jumlah kenaikan hasil sebelumnya dan apabila terus dibubuhkan satu kesatuan input lagi, akibatnya output yang dihasilkan akan menurun dan sampai pada suatu penambahan satu satuan input tertentu hasilnya akan negatif. Kejadian ini menujukkan berlakunya hukum kenaikan hasil yang semakin menurun atau "the law of diminishing return" (Sugiarto, dkk, 2005).

\section{Biaya Usahatani Padi Sawah}

Biaya usahatani dalam penelitian ini adalah besarnya biaya yang dikeluarkan selama proses produksi usahatani padi sawah pada satu tahun musim tanamr, yang dinyatakan dalam satuan rupiah per hektar per tahun. Jenis biaya dalam penelitian ini dibedakan atas dua kategori, yaitu biaya tetap dan biaya variabel. Biaya tetap terdiri dari penyusutan peralatan pajak lahan, sedangkan biaya variabel terdiri dari biaya pengadaan benih, pupuk, obat-obatan dan biaya pengadaan tenaga kerja. Berikut ini akan dijabarkan secara rinci mengenai biaya dalam usahatani di Kawasan Persawahan Amohalo Kecamatan Baruga Kota Kendari.

\section{Biaya Penyusutan dan Pajak Lahan}

Dalam melakukan kegiatan usahatani, peran peralatan sangat penting terutama dalam hal pengolahan lahan, penyiangan ataupun panen. Pada daerah penelitian di Kawasan Persawahan Amohalo, peralatan yang digunakan dalam melakukan kegiatan usahatani padi sawah adalah parang, cangkul, arit, sabit, sprayer, dan traktor. Sedangkan untuk biaya pajak lahan usahatani telah ditetapkan oleh Pemerintah Kota Kendari, yang besarnya tergantung. Luasan lahan yang dimiliki oleh masing-masing petani. Rata-rata nilai pajak lahan ini, dapat dilihat pada Lampiran 7 yaitu sebesar Rp 1.00.000,-/ha/thn. Berikut ini disajikan besarnya nilai penyusutan dari berbagi peralatan yang digunakan oleh petani padi sawah di Kawasan Persawahan Amohalo. 
Tabel 3. Nilai Penyusutan Pada Usahatani Padi Sawah Di Kawasan Persawahan Amohalo Kecamatan Baruga Kota Kendari

\begin{tabular}{clr}
\hline No & Uraian & $\begin{array}{c}\text { Nilai Penyusutan } \\
(\mathrm{Rp})\end{array}$ \\
\hline 1 & Maksimal & $1.552 .500,00,-$ \\
2 & Minimal & $22.750,00,-$ \\
3 & Rataan & $220.167,81,-$ \\
\hline
\end{tabular}

Sumber: Data Primer Diolah

Tabel 3 menunjukkan bahwa nilai penyusutan dari masing-masing petani responden bervariasi, berkisar antara Rp22.750,- sampai Rp1.552.500,- dengan rata-rata nilai penyusutan sebesar Rp220.168,-. Nilai penyusutan ini diperoleh dengan menggunakan rumus atau persamaan \{jumlah alat (harga sekarang - harga lama)/umur ekonomis\}. Terjadinya variasi biaya dalam penyusutan ini, dapat disebabkan karena perbedaan jenis peralatan yang digunakan selama proses produksi terjadi. Hal ini akan berdampak terhadap kemampuan fisik alat dalam bekerja, sehingga nilai ekonomi dari alat tersebut akan susut.

\section{Biaya Penggunaan Benih}

Benih merupakan sarana produksi yang mutlak diperlukan dalam berusahatani. Tanpa adanya benih maka mustahil suatu produksi akan dihasilkan Besarnya nilai benih yang dikeluarkan oleh petani responden usahatani padi sawah disajikan pada Tabel 4.

Tabel 4. Nilai Benih Pada Usahatani Padi Sawah Di Kawasan Persawahan Amohalo Kecamatan Baruga Kota Kendari

\begin{tabular}{clr}
\hline No & Uraian & $\begin{array}{r}\text { Nilai Benih } \\
(\mathrm{Rp} / \mathrm{ha} / \mathrm{thn})\end{array}$ \\
\hline 1 & Maksimal & $1.333 .333,33,-$ \\
2 & Minimal & $293.333,-$ \\
3 & Rataan & $610.985,18,-$ \\
\hline
\end{tabular}

Sumber: Data Primer Diolah

Tabel 4 menunjukkan besarnya biaya yang dikeluarkan oleh petani dalam pengadaan benih bervariasi, berkisar antara
Rp293.333,- $\quad$ sampai $\quad$ Rp1.333.333,33,/ha/thn, dengan biaya rata-rata sebesar Rp.610.985,18,-/ha/thn. Bervariasinya nilai benih ini, dapat disebabkan oleh jumlah fisik benih yang digunakan oleh masing-masing petani bervariasi. selain itu, juga varietas benih yang digunakan oleh petani berbedabeda, sehingga akan berdampak terhadap harga dari benih itu sendiri.

\section{Biaya Penggunaan Pupuk}

Biaya penggunaan pupuk yang dimaksud dalam penelitian ini adalah besarnya total biaya penggunaan pupuk yang digunakan petani responden selama satu tahun musim tanam. Petani padi sawah di Kawasan Persawahan Amohalo menggunakan lima jenis pupuk yang terdiri dari pupuk urea, TSP, poska, supertani dan pupuk organik (kompos). Besarnya biaya penggunaan pupuk tersebut bervariasi tergantung dari jumlah fisik dan harga per unitnya. Besarnya total nilai pupuk yang dikeluarkan oleh petani responden usahatani padi sawah di Kawasan Persawahan Amohalo disajikan pada Tabel 5.

Tabel 5. Nilai Pupuk Pada Usahatani Padi Sawah Di Kawasan Persawahan Amohalo Kecamatan Baruga Kota Kendari

\begin{tabular}{|c|c|c|}
\hline No & Uraian & $\begin{array}{l}\text { Nilai Pupuk } \\
\text { (Rp/ha/thn) }\end{array}$ \\
\hline 1 & Maksimal & $4.145 .454,55,-$ \\
\hline 2 & Minimal & $400.000,00,-$ \\
\hline 3 & Rataan & $1.453 .743,93,-$ \\
\hline
\end{tabular}

Tabel 5 menunujukan ada perbedaan biaya yang digunakan oleh masing-masing responden di lokasi peneltian, dengan biaya rata-rata sebesar Rp1.453.743,93,-Perbedaan atau bervariasinya nilai dari pupuk tersebut dapat disebabkan oleh faktor harga dan jumlah fisik dari pupuk itu sendiri. Sehingga besar kecilnya biaya yang dikeluarkan petani responden dalam pengadaan input ini, tentunya akan berdampak terhadap penerimaan dan pendapatan yang akan diperoleh petani tersebut. 


\section{Biaya Penggunaan Obat-Obatan}

Dalam penelitian ini diperoleh informasi bahwa besarnya penggunaan obatobatan dalam usahatani padi sawah tergantung dari besar kecilnya frekuensi penyerangan hama. Hal ini tentunya akan berpengaruh terhadap besarnya biaya yang dikeluarkan petani dalam pengadaan obatobatan. Besarnya biaya yang dikeluarkan petani responden dalam usahatani padi sawah bervariasi, berkisar antara Rp220.000,- sampai Rp1.900.000,-/ha/thn, dengan biaya rata-rata sebesar Rp654.000,/ha/thn. Besarnya biaya yang dikeluarkan petani responden penggunaan obat-obatan dalam usahatani padi sawah di Kawasan Persawahan Amohalo disajikan pada Tabel 6.

Tabel 6.Nilai Obat-Obatan Pada Usahatani Padi Sawah Di Kawasan Persawahan Amohalo Kecamatan Baruga Kota Kendari

\begin{tabular}{clc}
\hline No & Uraian & $\begin{array}{c}\text { Nilai Obat-Obatan } \\
(\mathrm{Rp} / \mathrm{ha} / \mathrm{thn})\end{array}$ \\
\hline 1 & Maksimal & $1.900 .000,-$ \\
2 & Minimal & $220.000,-$ \\
3 & Rataan & $654.000,-$ \\
\hline
\end{tabular}

Sumber: Data Primer Diolah

\section{Biaya Penggunaan Tenaga Kerja}

Tenaga kerja yang digunakan petani responden dalam usahatani padi sawah terdiri dari tenaga kerja keluarga dan tenaga kerja sewa. Biaya tenaga kerja yang dimaksud dalam penelitian ini adalah besarnya seluruh biaya tenaga kerja yang dikeluarkan oleh petani respondeni selama kegiatan produksi pada satu musim tanam terakhir. Besarnya biaya penggunaan tenaga kerja oleh petani padi sawah di Kawasan Persawahan Amohalo berkisar antara Rp 353.000 - 1.034.000,- dengan rata-rata per hektar sebesar Rp 623.896,05,-. Biaya Tenaga kerja disajikan pada Tabel 7.
Tabel 7. Biaya Tenaga Kerja Pada Usahatani Padi Sawah Di Kawasan PersawahanAmohalo K ecamatan Baruga Kota Kendari

\begin{tabular}{clr}
\hline No & Uraian & $\begin{array}{c}\text { Biaya Tenaga } \\
\text { Kerja } \\
(\mathrm{Rp} / \mathrm{ha} / \mathrm{thn})\end{array}$ \\
\hline 1 & Maksimal & $1.900 .000,-$ \\
2 & Minimal & $220.000,-$ \\
3 & Rataan & $654.000,-$ \\
\hline Sumber: Data Primer Diolah &
\end{tabular}

Sumber: Data Primer Diolah

Dari Tabel 7 terlihat jelas bahwa biaya penggunaan tenaga kerja di tiap-tiap petani responden berbeda-beda. Bervariasinya biaya penggunaan tenaga kerja yang digunakan oleh masing-masing petani responden, dapat disebabkan oleh perbedaan jenis atau macam kegiatan dalam usahatani.

\section{Penerimaan dan Pendapatan Usahatani Padi Sawah}

Penerimaan yang dimaksud dalam penelitian ini adalah besarnya jumlah produksi dan harga produksi gabah kering panen (GKP), yang dinyatakan dalam satuan $\mathrm{Rp} / \mathrm{ha} / \mathrm{thn}$. Sedangkan pendapatan merupakan selesih antara total jumlah penerimaan dan total biaya usahatani, yang juga dinyatakan dalam satuan $\mathrm{Rp} / \mathrm{ha} / \mathrm{thn}$. Berikut ini akan disajikan secara rinci mengenai biaya produksi, penerimaan dan pendapatan oleh petani responden di Kawasan Persawahan Amohalo Kecamatan Baruga. 
Tabel 8. Analisis Usahatani Padi Sawah di Kawasan Persawahan Amohalo

\begin{tabular}{|c|l|r|}
\hline No & Uraian & Nilai (Rp/ha/thn) \\
\hline \multirow{2}{*}{1.} & Biaya Tetap: & \\
& a. Penyusutan Alat & $220.167,81,-$ \\
& b. Pajak Lahan & $1.475 .757,58,-$ \\
\cline { 2 - 3 } & Tota Biaya Tetap & $1.695 .925,39,-$ \\
\hline \multirow{2}{*}{.} & Biaya Variabel: & \\
& a. Benih & $610.985,18,-$ \\
& b. Pupuk & $1.453 .743,93,-$ \\
& c. Obat-Obatan & $654.000,00,-$ \\
& d. Tenaga Kerja & $6.500 .093,31,-$ \\
\hline & Total Biaya Variabel & $9.218 .822,42,-$ \\
\hline 3 & Total Biaya Produksi & $10.914 .747,81,-$ \\
\hline 4. & Penerimaan & $18.631 .043,39,-$ \\
\hline 5. & Pendapatan & $7.716 .295,58,--$ \\
\hline 6. & R/C-Ratio & 1,69 \\
\hline 7. & B/C-Ratio & 0,69 \\
\hline
\end{tabular}

Sumber: Data Primer Diolah

Tabel 8 menunjukkan bahwa biaya terbesar yang dikeluarkan oleh petani responden dalam berusahatani adalah biaya tenaga kerja, yaitu Rp6.500.093,31,- per hektar /thn, sedangkan biaya terendah terletak pada biaya penyusutan peralatan, yaitu sebesar Rp220.167,81,-. Selain itu, dari Tabel 18 juga diketahui bahwa petani padi sawah di Kawasan Persawahan Amohalo Kecamatan Baruga dalam melakukan kegiatan produksi memperoleh keuntungan yang relatif kecil . Hal ini dapat dilihat dari jumlah penerimaan yang mampu menutupi seluruh biaya produksi yaitu sebesar Rp10.914.747,81,-/ha/thn, dengan R/C-ratio sebesar 1,69. Nilai ini menunjukkan bahwa setiap pengeluaran sebesar Rp1,-, maka akan menyebabkan kenaikan penerimaan sebesar Rp1,69,-. Hal ini dapat dikatakan bahwa penggunaan biaya pada usahatani padi sawah di Kawasan Persawahan Amohalo relatif efisien, karena nilai $\mathrm{R} / \mathrm{C}$-ratio > 1 .

Jika nilai penerimaan dan pendapatan yang diperoleh petani dari usahatani padi sawah di Kawasan Persawahan Amohalo dikonversi dalam satuan bulan, maka penerimaan dan pendapatan yang diperoleh masing-masing hanya sebesar Rp1.552.586,95,-/bulan dan Rp643.024,63,-/bulan. Nilai pendapatan ini sangat kecil bila dibandingkan dengan pemenuhan kebutuhan sehari-hari petani. Pada kondisi seperti ini sesungguhnya petani dalam kondisi yang merugi. Hal ini dapat digambarkan pada nilai B/C-ratio yang memperoleh nila sebesar 0,69 (B/C-ratio < 1), yang berarti bahwa setiap penambahan biaya sebesar Rp1,- maka akan menyebabkan kenaikan pendapatan sebesar Rp0,69,- (kenaikan pendapatnnya sangat lamban). Olehnya itu untuk lebih meningkatkan jumlah pendapatan, diperlukan kombinasi penggunaan input yang efektif dan efisien dengan cara mengintensifkan penggunaan lahan atau melakukan kombinasi usahatani pada lahan yang sama dengan memanfaatkan ketersedian sumberdaya, guna pencapaian produksi total yang optimum dan pendapatan yang maksimal.

\section{Analisis Usaha Ternak Itik}

Analisis usahaternak itik bertujuan untuk memberikan gambaran apakah usaha ini mempunyai prospek untuk dikembangkan atau tidak. Berdasarkan hasil identifaksi lapangan, diperoleh informasi bahwa petani padi sawah yang berada di Kawasan Persawahan Amohalo tidak semua memiliki atau memelihara ternak itik. Dari 33 responden yang ditemui hanya berjumlah 
6 orang yang memiliki ternak itik, sehingga dalam análisis ini, rata-rata biaya dan penerimaan per bulan dari ke enam responden inilah yang dilakukan estimasi untuk memberikan gambaran kelayakan usaha.

Tabel 9 menunjukkan bahwa petani padi sawah di Kawasan Persawahan Amohalo yang melakukan pemelihraan itik memperoleh keuntungan. Hal ini dapat dilihat dari jumlah penerimaan yang mampu menutupi seluruh biaya produksi yaitu sebesar Rp800.000,-/bulan, dengan R/Cratio sebesar 3,37. Nilai ini menunjukkan bahwa setiap pengeluaran sebesar Rp1,maka akan menyebabkan kenaikan penerimaan sebesar Rp3,37,-. Hal ini dapat dikatakan bahwa usahaternak itik yang dilakukan oleh petani padi sawah di Kawasan Persawahan Amohalo layak untuk dikembangka, karena nilai $\mathrm{R} / \mathrm{C}$ rationya lebih besar dari 1 (satu). Jika nilai penerimaan dan pendapatan yang diperoleh petani dari usahatani padi sawah di Kawasan Persawahan Amohalo dikonversi dalam satuan tahun, dengan asumsi variabelvariabel lain dianggap tetap, maka penerimaan dan pendapatan yang diperoleh masing-masing sebesar Rp9.600.000,- tahu dan Rp6.748.200,-/tahun.
Tabel 9. Analisis Usahaternak Itik di Kawasan Persawahan Amohalo

\begin{tabular}{|c|l|c|}
\hline No & Uraian & Nilai (Rp/bulan) \\
\hline 1. & Total Biaya & $237.651,-$ \\
\hline 2. & Penerimaan & $800.000,-$ \\
\hline 3. & Pendapatan & $562.350,-$ \\
\hline 4. & R/C-Ratio & 3,37 \\
\hline 5. & B/C-Ratio & 2,37 \\
\hline \multicolumn{3}{|c|}{ Sumber: Data Primer Diolah } \\
\hline
\end{tabular}

\section{Integrasi Usahatani Padi Sawah dan Ternak Itik}

Usaha agribisnis di sektor pertanian secara monokultur telah terbukti sangat rentan terhadap risiko kerugian, karena harga jual produk pertanian yang umumnya berfluktuasi dari waktu ke waktu. Oleh karena itu, diversifikasi (penganekaragaman) jenis usaha baik secara vertikal maupun horizontal merupakan upaya untuk mengurangi risiko ketergantungan terhadap usaha monokultur. Dalam upaya mewujudkan hal tersebut perlu inovási teknologi yang sesuai untuk diintegrasikan dalam usahatani terpadu dengan mengoptimalkan sumberdaya yang tersedia, dan secara teknis, ekonomi dan sosial budaya layak dan dapat diterima oleh masyarakat secara berkelanjutan.

Tabel 10. Analisis Usahatanai Padi Sawah yang Diintegrasikan Dengan Ternak Itik Di Kawasan Persawahan Amohalo, Tahun 2014

\begin{tabular}{lcrr}
\hline \multicolumn{1}{c}{ Uraian } & $\begin{array}{c}\text { Nilai } \\
\text { Tanaman Padi } \\
(\mathrm{Rp} / \mathrm{th})\end{array}$ & $\begin{array}{c}\text { Nilai } \\
\text { Ternak Itik } \\
(\mathrm{Rp} / \mathrm{th})\end{array}$ & $\begin{array}{c}\text { Nilai } \\
\text { Integrasi Padi } \\
\text { Sawah dan Itik } \\
(\mathrm{Rp} / \mathrm{th})\end{array}$ \\
\hline Biaya Produksi & $10,914,747.81$ & $2,851,812.00$ & $13,766,559.81$ \\
Penerimaan & $18,631,043.39$ & $9,600,000.00$ & $28,231,043.39$ \\
Pendapatan & $7,716,295.58$ & $6,748,200.00$ & $14,464,495.58$ \\
R/C-Ratio & 1.71 & 3.37 & 2.05 \\
B/C-Ratio & 0.71 & 2.37 & 1.05 \\
\hline
\end{tabular}

Sumber: Data Primer Diolah

Di Kawasan Persawahan Amohalo Kecamatan Baruga, integrasi antara tanaman padi sawah dan ternak itik belum diusahakan secara masksmal, hal ini dapat dilihat dari 33 responden yang teliti, ada 6 responden yang mengusahakan padi sawah sawah sambil memelihara itik. Jenis itik yang dipelihara adalah itik petelur, sehingga yang diharapkan hasil produksinya adalah telur. Jenis itik ini dapat dipanen setiap harinya dan biasanya dapat bertelur 1 butir per hari per ekor. Meskipun dalam hasil 
penelitian ini yang dianalisis hanya 6 responden yang memelihara itik, namun dapat memberikan gambaran usaha, apakah diperoleh keuntungan atau tidak. Gambaran hasil usaha mengenai integrasi tanaman padi sawah dan ternak itik di Kawasan Persawahan Amohalo, disajikan pada Tabel 10.

$\begin{array}{rrrr}\text { Tabel } 10 & \text { menunjukkan } & \text { bahwa } \\ \text { dengan } & \text { adanya } & \text { integrasi } & \text { atau }\end{array}$ penggambungan usaha dalam satu lahan pertanian, maka akan memberikan dampak yang positif terhadap pendapatan petani secara keseluruhan. Sebagaimana dalam pembahasan sebelumnya, bahwa pada usahatani padi sawah secara tunggal, ratarata petani di Kawasan Persawahan Amohalo memiliki pendapatan yang relatif rendah (Rp643.024,63,-/bulan), yang mana nilai pendapatan ini sangat kecil bila dibandingkan dengan pemenuhan kebutuhan sehari-hari petani.

Namun jika pada usahatani padi sawah diintegrasikan dengan ternak itik, maka taksiran pendapatan bersih per bulan yang diperoleh petani di Kawasan Persawahan Amohalo adalah sebesar Rp1.205.374,63,- atau sebesar Rp14.464.495,58,- per tahunnya, dengan nilai $\mathrm{R} / \mathrm{C}$ ratio sebesar 2,05 dan $\mathrm{B} / \mathrm{C}$ ratio sebesar 1,05. Nilai ini menunjukkan bahwa setiap penggunaan biaya pada usahatani padi sawah yang diintegrasikan dengan ternak itik sebesar Rp1,- maka akan meningkatkan jumlah penerimaan sebesar $\mathrm{Rp} 2.05,-$ dan jumlah pendapatan bersih sebesar Rp1.05,-. Dengan demikian pola usahatani padi sawah yang terintegrasi dengan ternak itik, lebih efisien dan menguntungkan dari pada usahatani tunggal. Sehingga dapat dikatakan bahwa usahatani padi sawah yang terintegrasi dengan ternak itik memberikan tambahan atau peningkatan pendapatan sebesar 53,35\% dari usahatani tunggal. Hal ini tentunnya akan memberikan manfaat yang sangat besar bagi masyarakat tani yang berada di Kawasan Persawahan Amohalo Kecamatan Baruga Kota Kendari.

\section{KESIMPULAN}

Berdasarkan hasil penelitian disimpulkan (1) pada usahatani tungal, jumlah pendapatan bersih yang diperoleh petani padi sawah di Kawasan Persawahan Amohalo adalah sebesar Rp7.716.295,58,per tahunnya,- atau hanya sebesar Rp.643.024.63,- per bulanya, (2) Pada usahatani integrasi, jumlah pendapatan bersih petani di Kawasan Persawahan Amohalo adalah sebesar Rp14.464.495,58,per tahunnya, atau sebesar Rp.1.205.374,63,-,dan (3) pola usahatani padi sawah yang terintegrasi dengan ternak itik, lebih efisien dan menguntungkan dari pada usahatani tunggal. Pada usahatani tunggal diperoleh nilai $\mathrm{R} / \mathrm{C}$ ratio sebesar 1,69 sedangkan usahatani yang terintegrasi diperoleh nilai $\mathrm{R} / \mathrm{C}$ ratio sebesar 2,05.

\section{UCAPAN TERIMA KASIH}

Tim penulis mengucapkan terimakasih kepada Pemerintah Daerah Kota Kendari, atas kepercayaannya dalam mendanai pelaksanaan riset ini. Penelitian ini terlaksana atas kerjasama Pemerintah Daerah Pemerintah Daerah Kota Kendari dengan Lembaga Penelitian dan Pengabdian Kepada Masyarakat Universitas Halu Oleo Kendari. Penulis juga tidak lupa mengucapkan penghargaan yang setinggitinggi kepada seluruh masyarakat pada Kawasan Amohalo, terutama petani padi sawah atas segala waktu dan informasinya selama kegiatan penelitian berlangsung.

\section{DAFTAR PUSTAKA}

Atmojo, SW. Pertanian Organik, Integrasi ternak dan Tanaman. Solo Pos, 7 Maret 2007

Basuki, S dan MN Setyaperma., 2012. Pemanfaatan Cuaca ekstrim dalam pembesaran itik dalam system usahatani padi (Studi Kasus di Kabupaten Brebes). Makalah. Disampaikan pada Seminar Nasional Kedaulatan pangan dan energi. Fakultas Pertanian Universitas Trunojoyo Madura. Juni, 2012

Badan Pusat Statistik Kota Kendari 2014. Kota Kendari dalam angka. Kendari. 
Beattie, B.R dan C.R. Taylor. 1996. Ekonomi Produksi. Gadjah Mada University Press. Jogyakarta.

Daniel, M. 2002. Pengantar Ekonomi Pertanian. Bumi Aksara. Jakarta

Diwyanto, K., B.R. Prawiradiputra, dan D. Lubis. 2002. Integrasi tanaman-ternak dalam pengembangan agribisnis yang berdaya saing, berkelanjutan dan berkerakyatan. Wartazoa, Buletin Ilmu Peternakan Indonesia 12(1):1-8.

Hernanto, F. 1991. Ilmu Usahatani. Penebar Swadaya. Jakarta.

Karda, I.W. dan Spudiati. 2012. Meningkatkan Produktifitas Lahan Marginal Melalui Integrasi Tanaman Pakan dan Ternak Ruminansia. Fakultas Peternakan Universitas Mataram. ntb.litbang.deptan.go.id diakses tanggal 1 Mei 2012.

Kartasapoetra. 1988. Pengantar Ekonomi Produksi Pertanian. Bina Aksara. Jakarta

Kelana, S. 1996. Teori Ekonomi Mikro. Raja Grafindo Persada. Jakarta

Mahfudz, LD, dan E. Prasetya, 2005. Tingkat efisiensi teknis dan ekonomis pada sistem pemeliharaan terpadu antara tanaman padi dengan itik local jantan. J. Indon.Trop. Anim. Agric. 30 (1) March

Mubyarto. 1989. Pengantar Ekonomi Petanian. LP3ES. Jakarta.

Murtidjo, B, 1993. Mengelola Itik. PT. Gramedia. Jakarta.

Pappas, J.K dan M. Hirschey. 1995. Ekonomi Manajerial. Binarupa Aksara. Jakarta.

Pujiatmoko. 2009. Pertanian Terpadu Padi dan Itik di Jepang . Jurnal Atani Tokyo.

Rencana Tata Ruang Wilayah Kota Kendari 2007-2020.

Sahara D. dan Idris. 2010. Efisiensi Produksi Sistem Usahatani Padi pada Lahan Sawah Irigasi Teknishttp://ejournal.unud.ac.id/abstrak/ (7)socadewisahara_dan_idris_efisiensi_ produksi.pdf

Santoso, B., 1992. Paket Satuan Pelajaran: Manajemen Usahatani. SPP. Bone.

Setioko, A.R, S. Iskandar, Y.C. Raharjo, T.D. Soedjana, T. Murtisarai, M.Purba,.E. Estuningsih, N. Sunandar,; D. Sarosa. Model Usaha Ternak Itik dalam Sistem Pertanian dengan Indek Pertanaman padi tiga kali per Tahuan IP 276. Pengaruh Timbali balik antara Peternak dan Petani. JITV. 5(1) Tahun 2000
Sinulingan. 1997. Irigasi di Indonesia. Bharata. Jakarta.

Soedarso. 1991. Pengantar Ekonomi Makro. Rineka Cipta. Jakarta.

Soeharjo, A. dan D. Patong. 1984. Sendi-sendi Pokok Usahatani. Universitas Hasanuddin. Ujung Pandang.

Soekartawi. 1990. Teori Ekonomi Produksi dengan Pokok Bahasan Analisis CoobDouglas. Rajawali Press. Jakarta.

1993. Prinsip Dasar Ekonomi Pertanian. Raja Grafindo Persada. Jakarta.

1995. Analisis Usahatani. Raja Grafindo Persada. Jakarta.

............. 2001. Agribisnis, Teori dan Aplikasinya. Raja Grafindo Persada. Jakarta.

2002. Prinsip Dasar Manajemen Pemasaran Hasil-Hasil Pertanian; Teori dan Aplikasinya. Raja Grafindo Persada. Jakarta.

Suamba, N.M.A.C.L.K, dan I.G.A.A. Ambarawati., Analisis Efisiensi Usahatani Padi Sawah, (Studi Kasus di Subak Guama, Kecamatan Marga, Kabupaten Tabanan) E-Journal Agribisnis dan Agrowisata ISSN: 23016523 Vol. 1, No. 1, Juli 2012.

Sudaryani, S. 2008. Upaya peningkatan Kesejahteraan dan daya saing Peternak Jawa Barat. Makalah. Pusat Ikubator Universitas Padjajaran. Bandung.

Sugiarto., 2005. Ekonomi Mikro: Sebuah Kajian Komprehensif. Gramedia Pustaka Utama. Jakarta.

Sugiyono. 2012. Metode Penelitian Kombinasi (Mixed Methods). Alfabeta. Bandung.

Sukirno, S. 1998. Pengantar Teori Mikroekonomi. Raja Grafindo Persada. Jakarta.

Sumarjono, 2004. Ilmu Ekonomi Produksi. Diktat Kuliah. Program Studi Sosial Ekonomi Peternakan Universitas Diponegoro. Semarang.

Supranto, J. 1997. Pengukuran Tingkat Kepuasan Pelanggan. Rineka Cipta. Jakarta.

Syarif, R., 1998. Produktivitas. Angkasa. Bandung.

Tohir, K.A. 1991. Seuntai Pengetahuan Usahatani Indonesia. Rineka Cipta. Jakarta.

Wiguna. 2008. Pembangunan Pertanian di Bali. Diunduh 1 Juni 2014.Http://www.deptan.go.id. 